\title{
PENGARUH PENYAJIAN MATERI DALAM BENTUK MEDIA KOMIK TERHADAP MINAT BACA DAN HASIL BELAJAR
}

\section{IMPACT OF MATERIAL PRESENTATION IN COMICS MEDIA TOWARDS READING INTEREST AND LEARNING OUTCOMES}

\author{
Ira Wulandari Suparman ${ }^{1}$, Marlina Eliyanti ${ }^{2}$, Eli Hermawati ${ }^{3}$ \\ 1,2,3 PGSD, FKIP, Universitas Kuningan \\ irawulandari.s@gmail.com ${ }^{1}$, marlina@uniku.ac.id ${ }^{2}$, eli.hermawati@uniku.ac.id ${ }^{3}$
}

\begin{abstract}
Pengutipan: Suparman, I. W., Eliyanti, M., \& Hermawati, E. (2020). Pengaruh penyajian materi dalam bentuk media komik terhadap minat baca dan hasil belajar. Pedagogi: Jurnal Penelitian Pendidikan, 7 (1), hlm 57-64
\end{abstract}

Diajukan: 13-05-2020

Diterima: 23-05-2020

Diterbitkan: 31-05-2020

\begin{abstract}
ABSTRAK
Masalah dalam penelitian ini yaitu rendahnya minat baca siswa terhadap materi pelajaran yang berdampak pada menurunnya hasil belajar siswa kelas III SD Negeri Kertaungaran. Materi bacaan perlu dibuat menarik, penuh warna, dan gambar yang dapat mengembangkan imajinasi. Bacaan menarik tersebut berupa media komik yang dapat diterapkan dalam pembelajaran. Tujuan dari penelitian ini adalah untuk mengetahui: (1) perbedaan hasil belajar siswa pada kelas yang menggunakan penyajian materi dalam bentuk media komik dengan kelas yang tidak menggunakan penyajian materi dalam bentuk media komik setelah perlakuan, (2) perbedaan peningkatan hasil belajar siswa pada kelas yang menggunakan penyajian materi dalam bentuk media komik dengan kelas yang tidak menggunakan penyajian materi dalam bentuk media komik, dan (3) pengaruh penyajian materi dalam bentuk media komik terhadap minat baca siswa kelas III pada pelajaran IPS materi Kerjasama di SDN Kertaungaran. Penelitian ini menggunakan metode quasi eksperimen dengan non equivalent control group design. Jumlah siswa yang diteliti dalam penelitian ini sebanyak 61 siswa, terdiri dari 31 siswa kelas III A (kelas eksperimen) dan 30 siswa III B (kelas kontrol). Berdasarkan hasil pengolahan dan analisis data, hasil belajar siswa sebelum perlakuan tidak jauh berbeda. Namun, setelah perlakuan menggunakan media komik hasil belajar berbeda secara signifikan. Siswa yang belajar menggunakan media komik mengalami peningkatan nilai rata-rata mencapai KKM. Peningkatan hasil belajar ini juga mempengaruhi minat baca siswa terhadap komik secara positif. Oleh karena itu, guru disarankan menggunakan media komik untuk menarik minat baca siswa terhadap materi pelajaran, sehingga hasil belajar siswa meningkat.
\end{abstract}

Kata Kunci: minat baca; hasil belajar; media komik kerjasama

\section{ABSTRACT}

The problem in this study was the lack of students reading interest towards subject matter which has an impact on the decreasing learning outcomes of third-grade students in SD Negeri Kertaungaran. Reading material needed to be interesting, colorful, and has a picture that can develop the imagination. The interesting reading in our study was a comic media that can be applied in learning. The purpose of this study was to found: (1) student learning outcomes differences in classes using material presented in comic media and classes that did not use the material presented in comic media after treatment, (2) differences in the increase 
Ira Wulandari Suparman, Marlina Eliyanti, \& Eli Hermawati

PENGARUH PENYAJIAN MATERI DALAM BENTUK MEDIA KOMIK TERHADAP MINAT BACA DAN HASIL BELAJAR

in student learning outcomes in classes that are using the material presented in comic media with classes that did not use the material presented in comic media, and (3) the impact of presenting material in comic media on the reading interest in third-grade students in Social Studies about Collaboration at SDN Kertaungaran. This study used a quasi-experimental method with a non-equivalent control group design. The participant in this study was 61 students, consisting of 31 students in III A (experimental class) and 30 students in III B (control class). Based on the results of data processing and analysis, student learning outcomes before treatment were not much different. However, after treatment using comic media, the learning outcomes differed significantly. Students who learn with comic media have an average above from minimum mastery criteria. This increase in learning outcomes also positively affects students' interest in reading comics. Therefore, teachers are advised to use comic media to attract students' interest in reading subject matter, so that student learning outcomes improve.

Keywords: reading interest; learning outcomes; cooperation comics media 


\section{PENDAHULUAN}

Pengetahuan merupakan suatu hal yang penting bagi kehidupan manusia. Pengetahuan dapat diperoleh dari mana saja, baik itu melalui pendidikan formal, informal maupun nonformal. Salah satu cara memperoleh pengetahuan adalah melalui kegiatan membaca, terutama membaca buku pelajaran. Dengan membaca manusia memperoleh pengetahuan baik di lingkungan pendidikan maupun di lingkungan masyarakat. Menurut Crawley \& Mountain dalam Rahim (2009: 2) membaca adalah suatu yang rumit yang melibatkan banyak hal, tidak sekedar melafalkan tulisan, tapi juga melibatkan aktivitas visual, berpikir, psikolinguistik, dan metakognitif. Untuk mencapai keberhasilan membaca yang baik salah satunya yaitu adanya minat.

Menurut Yulia (2005: 2) minat adalah fondasi bagi terbentuknya lifelong learner (pembelajaran sepanjang hayat), dengan menumbuhkan minat baca anak, kita sudah melakukan fondasi untuk mendorong anak kita menjadi pembelajar sepanjang hayat, karena buku adalah jendela dunia yang membawa kita maupun anak-anak kemana saja kita suka. Sedangkan menurut Marksheffel dalam Nuryanti (2008: 59) menjelaskan bahwa minat atau interest adalah pembawaan manusia, tetapi dapat dibentuk atau diusahakan, dipelajari dan dikembangkan.

Upaya yang dapat seorang guru lakukan dalam menarik minat baca siswa salah satunya yaitu kegiatan belajar di dalam kelas. Menurut Bruner dalam Winaputra (2008: 2) pada dasarnya belajar merupakan proses kognitif yang terjadi dalam diri seseorang. Ada tiga proses kognitif yang terjadi dalam belajar, salah satunya yaitu proses perolehan informasi baru, dapat terjadi melalui kegiatan membaca, mendengarkan penjelasan guru mengenai materi yang diajarkan atau mendengar, melihat audio visual dan lain-lain.

Permasalahannya tidak semua siswa senang membaca buku pelajaran ataupun hanya mendengarkan penjelasan guru. Sehingga hal ini berdampak terhadap hasil belajar siswa. Menurut Susanto (2013: 5) hasil belajar merupakan perubahan-perubahan yang terjadi pada diri siswa, baik yang menyangkut aspek kognitif, afektif dan psikomotorik sebagai hasil dari kegiatan belajar. Kegitan belajar yang kurang variatif dan tidak menyenangkan memperburuk hasil belajar siswa, apalagi jika siswa hanya disuruh membaca buku pelajaran yang penuh dengan teks padat.

Bagi siswa buku pelajaran adalah sesuatu yang membosankan, sulit dipahami, dan tidak menarik, ditambah lagi apabila guru mengajar hanya menggunakan metode ceramah. Meskipun buku-buku pelajaran saat ini sudah dilengkapi dengan gambar, namun masih belum dapat menarik minat baca siswa terhadap materi pelajaran sehingga hasil belajar pun menurun.

Menurut Arsyad (2000: 56) bahwa pentingnya penggunaan media dalam pembelajaran sebagai sumber belajar yang terintegrasi dapat mengantarkan pesan dan mendorong terjadinya proses belajar guna mencapai tujuan pembelajaran. Pemakaian media dalam proses belajar mengajar dapat membangkitkan keinginan dan minat siswa, membangkitkan motivasi dan rangsangan belajar, dan memicu suasana belajar yang menyenangkan sehingga hasil belajar cenderung lebih baik.

Hasil wawancara dengan guru kelas III SDN Kertaungaran menunjukan hasil belajar siswa menurun, rata-rata nilai hasil ulangan harian siswa pada mata pelajaran IPS masih banyak yang di bawah KKM yang ditetapkan sekolah yaitu 71. Data tersebut menunjukan dari 38 siswa pada kelas III A sebanyak 25 siswa atau 65,79\% dalam mata pelajaran IPS belum mencapai Kriteria Ketuntasan Minimal (KKM), dan sebanyak 13 orang atau 34,22\% siswa sudah mencapai Kriteria Ketuntasan Minimal (KKM). Sementara itu, siswa kelas III B dalam mata pelajaran IPS yang belum mecapai Kriteria Ketuntasan Minimal(KKM) sebanyak 20 siswa atau 57,14\%, dan sebanyak 15 siswa atau 42,86\% siswa sudah mencapai Kriteria Ketuntasan Minimal (KKM). 
Menurunnya hasil belajar siswa pada mata pelajaran IPS salah satunya dipengaruhi oleh rendahnya minat baca siswa terhadap buku pelajaran, artinya siswa tidak suka membaca buku pelajaran walaupun sudah ditugaskan membaca sebelum pelajaran dibahas, terutama pada mata pelajaran yang menyajikan banyak materi dalam bentuk teks padat daripada gambar seperti ilmu pengetahuan sosial. Ilmu pengetahuan social (IPS) sendiri menjadi mata pelajaran strategis untuk menyiapkan siswa menjadi warga Negara yang memiliki karakter dan kecakapan yang memadai sebagai bagian masyarakat sosial, dimana mata pelajaran yang disajikan pun tidak jauh dari kehidupan yang dialami siswa, misalnya pada materi kerjasama. Setiap manusia yang hidup di lingkungan sosial pasti harus dapat bekerjasama dengan lingkungan sekitar, karena pada dasarnya manusia tidak dapat hidup tanpa bantuan orang lain. Materi kerjasama dalam mata pelajaran IPS kelas III semester ganjil banyak menyajikan materi dalam bentuk teks yang padat daripada gambar, sehingga ketertarikan siswa membaca pada materi tersebut kurang.

Salah satu yang dapat dilakukan guru dalam menarik minat baca dan hasil belajar siswa adalah melalui penyajian materi dalam bentuk media komik. Komik merupakan bacaan yang disukai semua kalangan baik anak-anak sampai dewasa. Penyajian materi pada komik dalam bentuk gambar-gambar yang menarik, panel, balon baca, latar belakang, tokoh cerita, narasi hingga efek suara yang membuat cerita semakin menarik minat baca siswa dan membantu siswa dalam belajar. Melalui penyajian materi dalam bentuk komik, diharapkan dapat menarik minat baca siswa terhadap materi pelajaran, sehingga siswa dapat dengan mudah memahami materi yang disampaikan yang akhirnya berdampak pula pada peningkatan hasil belajar. Selain itu komik membuat materi pelajaran IPS yang abstrak terasa lebih konkret bagi siswa, hal ini sesuai dengan perkembangan berpikir siswa sekolah dasar yaitu konkrit atau nyata.

Hasil penelitian Hidayah \& Ulva (2017) menyimpulkan penggunaan media komik dalam pembelajaran IPS kelas IV materi Koprasi di MI Nurul Hidayah Roworejo Negerikaton Pesawaran, bahwa antusiasme siswa dalam membaca media komik yang diberikan cukup tinggi. Motivasi belajar siswa tampak meningkat dengan penggunaan media komik yang dikembangkan, siswa menyukai media komik yang dikembangkan, siswa mengatakan bahwa belajar menggunakan media komik lebih menyenangkan dibandingkan hanya mendengarkan penjelasan guru atau membaca buku teks yang telah ada. Hal ini sejalan dengan teori kognitif multimedia learning Mayer (2009:68), bahwa siswa yang belajar dengan kata-kata dan gambar-gambar bisa menghasilkan $89 \%$ lebih banyak solusi kreatif dalam tes transfer dibandingkan dengan siswa yang hanya belajar dengan kata-kata saja. Didukung dengan teori yang dikemukakan oleh Daryanto (2010:129) bahwa siswa cenderung menyukai buku yang bergambar, yang penuh warna dan divisualisasikan dalam bentuk realistis maupun kartun.

Sejalan dengan ketiga pendapat, Richi Ledi Aprianto \& Ningsih (2016) dalam jurnalnya yang berjudul: Pengaruh Media Pembelajaran Komik terhadap hasil belajar IPS Materi Bencana Alam pada siswa Kelas VI SD, menunjukkan setelah siswa diberikan media komik untuk dibaca sendiri ternyata terjadi peningkatan hasil belajar dari sebelumnya ratarata hasil belajar 67,3 menjadi rata-rata hasil belajar 77, 11 setelah posttest.

Berdasarkan permasalahan yang dikemukakan maka peneliti menggunakan media komik pada mata pelajaran IPS. Harapannya, penelitian ini dapat membuktikan adanya peningkatkan minat baca dan hasil belajar siswa pada materi pelajaran yang menyajikan materi dalam bentuk teks. 


\section{METODE PENELITIAN}

Metode penelitian yang digunakan dalam penlitian ini adalah metode quasi experimental design, dimana desain yang digunakan yaitu Nonequivalent Control Group Design. Dalam Penelitian ini dilakukan di SDN Kertaungaran tahun ajaran 2017-2018 dengan subjek peneliti siswa kelas III yang terdiri dari kelas 3A sebanyak 38 siswa sebagai kelompok eksperimen dan kelas 3B sebanyak 35 siswa sebagai kelompok kontrol.

Teknik pengumpulan data pada penelitian ini yaitu tes hasil belajar melalui pretest dan posttest dalam bentuk pilihan ganda, kuesioner (angket) dengan jenis angket tertutup, dan dokumentasi berupa catatan data siswa dan dokumen lainnya yang diperlukan. Tes pilihan ganda dimaksudkan untuk mengukur hasil belajar siswa. Angket digunakan untuk mengukur minat baca siswa. Sedangkan dokumentasi menjadi pelengkap dalam pengumpulan data ini.

Analisis data dalam penelitian adalah dengan mengolah data hasil tes akhir melalui pengujian instrumen dan uji persyaratan statistik. Uji instrumen yang dilakukan yaitu uji validitas, uji reliabilitas, tingkat kesukaran, dan daya pembeda. Hal ini dimaksudkan agar soal yang diberikan layak untuk mengukur hasil belajar siswa, dan mengukur tingkat kesukaran, serta daya pembeda dari tiap item soal yang diujikan. Sedangkan uji persyaratan statistik yaitu dengan mengolah hasil tes akhir melalui rumus statistik berupa uji normalitas, uji homogenitas, uji hipotesis (uji t) dan uji N-Gain.

\section{HASIL PENELITIAN DAN PEMBAHASAN}

Hasil penelitian pada siswa kelas III SDN Kertaungaran diketahui bahwa hasil belajar mata pelajaran IPS masih rendah. Rendahnya hasil belajar siswa kelas III SDN Kertaungaran dipengaruhi oleh beberapa faktor, diantaranya kurangnya penggunaan media pembelajaran pada mata pelajaran IPS sehingga pembelajaran menjadi tidak menarik dan siswa kesulitan memahami materi pelajaran. Selain itu, kurangnya minat baca siswa terhadap materi pelajaran juga menjadi faktor penyebab rendahnya hasil belajar.

Pada penelitian siswa diberi perlakuan dengan menggunakan media komik, media tersebut diterapkan di kelas IIIA sebagai kelas eksperimen sedangkan kelas IIIB sebagai kelas kontrol tidak menggunakan media. Tujuan penelitian ini untuk mengetahui perbedaan hasil belajar (posttest) dan perbedaan peningkatan (gain) anatara kelas eksperimen dan kelas kontrol, dan untuk mengetahui pengaruh minat baca terhadap materi pelajaran kerjasama pada mata pelajaran IPS di kelas III SDN Kertaungaran.

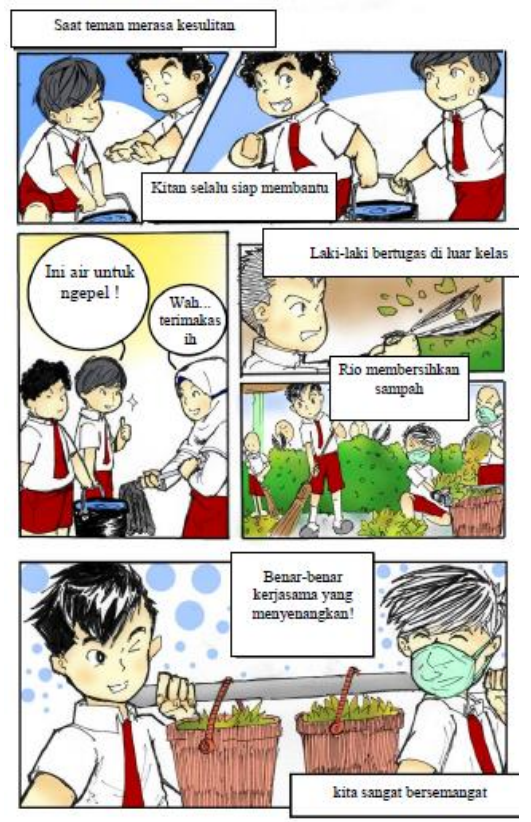

Gambar 1. Screenshot Media Komik Kerjasama 
Hasil analisis data awal (pretest) diketahui bahwa rata-rata hasil tes yang tidak jauh berbeda yaitu 55 dan 55,06. Hasil tersebut menunjukkan bahwa keadaan awal siswa kelas ekperimen dan kelas kontrol sebelum pembelajaran mempunyai kemampuan yang sama. Setelah mengetahui data hasil belajar siswa yang diperoleh dari tes awal (pretest) tersebut, selanjutnya diberikan perlakuan menggunakan media komik pada kelas eksperimen dan buku pegangan guru pada kelas kontrol untuk kemudian diperoleh hasil perhitungan kemampuan akhir siswa (posttest). Hasil analisis data akhir (posttest) menunjukkan perbedaan peningkatan hasil belajar antara kelas kontrol dan kelas eksperimen. Rata-rata nilai pada kelas kontrol 64,1 sedangkan kelas eksperimen 75,35, data tersebut menunjukkan hasil uji t sebesar 3,93 dimana $t_{\text {hitung }}>t_{\text {tabel }}$ yaitu 3,93 $>2,001$, sehingga dapat disimpulkan bahwa terdapat perbedaan hasil belajar siswa pada kelas yang menggunakan media komik dengan kelas yang tidak menggunakan media komik.

Analisis data selanjutnya yaitu melakuakan uji $n$-gain untuk mengetahui terdapat atau tidak terdapat perbedaan (gain) antara kelas eksperimen dengan kelas kontrol, dengan menggunakan uji perbedaan dua rata-rata (uji t) gain. Berdasarkan hasil analisis tersebut menunjukan nilai rata-rata n-gain pada kelas eksperimen sebesar 0,4 dan kelas kontrol sebesar 0,2 . Hasilnya dilihat dari uji $\mathrm{t} n$-gain diperoleh $\mathrm{t}_{\text {hitung }}(3,17)>\mathrm{t}_{\text {tabel }}(2,001)$ dengan ini menyatakan bahwa hipootesis diterima karena "Terdapat perbedaan peningkatan (gain) hasil belajar siswa pada kelas yang menggunakan penyajian materi dalam bentuk media komik dengan kelas yang tidak menggunakan penyajian materi dalam bentuk media komik".

Selain analisis pretest, posttest, dan $n$-gain, peneliti juga melakuakan analisis pengaruh media komik terhadap minat baca siswa. Data yang dianalisis yaitu data angket yang diisi oleh siswa kelas eksperimen (siswa yang mendapatkan perlakuan penyajian materi dalam bentuk media komik). Hasil angket tersebut ditafsirkan kedalam kalimat kualitatif apakah negatif, netral atau positif. Hasil analisis menunjukkan $8,77 \%$ siswa senang belajar menggunakan media komik, artinya bahwa pengaruh penyajian materi dalam bentuk media komik terhadap minat baca siswa pada materi IPS adalah positif.

Dari hasil analisis tersebut siswa yang menggunakan penyajian materi dalam bentuk media komik hasil belajarnya meningkat bila dibandingkan dengan siswa yang tidak menggunakan penyajian materi dalam bentuk media komik. Hal ini karena penggunaan media komik dalam pembelajaran dapat memudahkan siswa dalam memahami pelajaran dan mampu mengembangkan imajinasi siswa. Hal tersebut sejalan dengan pendapat Nurgiyantoro (2005: 409) dimana komik dapat merangsang daya imajinasi siswa dan memudahkan siswa memahami isi bacaan. Sementara penggunaan buku pegangan guru dalam pembelajaran tidak efektif meningkatkan hasil belajar siswa, karena buku pegangan guru hanya menyajikan materi yang berisi tekst padat dengan sedikit gambar, sehingga siswa kurang menyukai apa yang dibacanya yang menyebabkan siswa kesulitan memahami isi bacaan.

Dari data yang dipaparkan menunjukkan media komik dapat meningkatkan hasil belajar dan memberikan pengaruh positif terhadap minat baca siswa. Data di lapangan diketahui bahwa antusias siswa terhadap membaca komik lebih tinggi dibandingkan hanya membaca buku pelajaran atau buku pegangan guru. Terbukti dari hasil jawaban angket yang diberikan kepada siswa rata-rata nilai jawaban angket $8,77 \%$, dimana data tersebut menunjukkan pengaruh media komik terhadap minat baca berpengaruh positif. Hal ini sesuai dengan teori yang dikemukakan Sugiyono (2013: 199) bahwa apabila nilai angket menunjukkan nilai pernyataan bernilai 1 lebih dari setengah jawaban responden maka data berpengaruh positif. Sejalan dengan pendapat tersebut Darmono (2001: 189) mengemukakan bahwa minat baca siswa dapat tumbuh bila siswa diberikan bacaan-bacaan yang menarik. Menurut Daryanto (2010: 129) mengemukakan bacan yang menarik tersebut adalah bacaan- 
bacaan yang bergambar, yang penuh warna dan divisualisasikan dalam bentuk realistis maupun kartun.

Sedangkan berdasarkan penelitian sebelumnya yang dikemukakan Aprianto \& Ningsih (2016) menunjukkan penggunaan media komik dalam pembelajaran dapat meningkatkan hasil belajar siswa dari rata-rata 67,3 menjadi 77,11 setelah posttest. Menurut Fahyuni \& Fauji (2017) mengemukakan penggunaan media komik dalam pembelajaran dapat meningkatkan minat baca, hal tersebut dibuktikan melalui uji kelayakan validasi ahli didapat skor 93\% komik sangat layak / menarik untuk digunakan sebagai media pembelajaran dalam meningkatkan minat baca siswa terhadap materi pelajaran di SD Muhammadiyah 1 Sidoarjo. Dengan demikian dapat dijelaskan bahwa hasil penelitian yang dilakukan menggunakan media komik berpengaruh terhadap minat baca dan dapat meningkatkan hasil belajar siswa sejalan dengan teori dan kaidah yang berlaku.

Pada penelitian ini, telah dibuktikan bahwa terdapat pengaruh positif terhadap minat baca dan hasil belajar siswa menggunakan penyajian materi dalam bentuk media komik.

\section{SIMPULAN DAN SARAN}

Berdasarkan analisis data dan pembahasan yang telah disajikan, terdapat perbedaan antara kelas kontrol dan kelas eksperimen pada penelitian yang dilakukan di SDN Kertaungaran materi Kerjasama mata pelajaran IPS. Adapun simpulan dari hasil penelitian adalah: (1) Pengujian hipotesis nilai posttest atau setelah siswa mendapatkan perlakuan. Pengujian hipotesis menggunakan uji t (uji kesamaan dua rata-rata) dapat disimpulkan bahwa terdapat perbedaan hasil belajar siswa pada kelas yang menggunakan penyajian materi dalam bentuk media komik dengan kelas yang tidak menggunakan penyajian materi dalam bentuk media komik. Kelas yang menggunakan penyajian materi dalam bentuk media komik (kelas eksperimen) menunjukkan hasil belajar yang mencapai KKM; (2) Hasil analisis pengujian hipotesis menggunakan uji n-gain dapat disimpulkan bahwa terdapat perbedaan peningkatan hasil belajar siswa pada kelas yang menggunakan penyajian materi dalam bentuk media komik dengan kelas yang tidak menggunakan penyajian materi dalam bentuk media komik; dan (3) Dari hasil analisis data angket menunjukkan bahwa pengaruh penyajian materi dalam bentuk media komik terhadap minat baca siswa pada mata pelajaran IPS materi kerjasama di kelas III SDN Kertaungaran adalah positif. Hal ini menunjukkan rata-rata siswa lebih menyukai bacaan pelajaran dalam bentuk media komik daripada buku pelajaran pegangan guru atau buku pegangan siswa. Berdasarkan hasil tersebut maka peneliti menarik simpulan dari penelitian ini bahwa media pembelajaran komik berpengaruh positif terhadap minat baca dan dapat meningkatkan hasil belajar siswa. 
Ira Wulandari Suparman, Marlina Eliyanti, \& Eli Hermawati

PENGARUH PENYAJIAN MATERI DALAM BENTUK MEDIA KOMIK TERHADAP MINAT BACA DAN HASIL BELAJAR

\section{DAFTAR PUSTAKA}

Aprianto, R. L., \& Ningsih, S. D. (2016). Pengaruh media pembelajaran komik terhadap hasil belajar ips materi bencana alam siswa kelas VI sekolah dasar. Jurnal Penelitian Pendidikan, 8 (1), 1189-1249.

Arsyad, Azhar. (2000). Media pengajaran. Jakarta: Raja Grafindo Persada.

Darmono. (2001). Manajemen perpustakaan sekolah. Jakarta: Grasindo.

Fahyuni, E. F., \& Fauji, I. (2017). Pengembangan komik akidah akhlak untuk meningkatkan minat baca dan prestasi belajar siswa sekolah dasar. Islamic Education Journal, 1 (1), 17-26.

Hidayah, N., \& Ulva, R. K. (2017). Pengembangan media pembelajaran berbasis komik pada mata pelajaran ips kelas IV MI Nurul Hidayah Roworejo Negerikaton Pesawaran. Jurnal Pendidikan dan Pembelajaran Dasar, 4 (1), 34-46.

Mayer. (2009). Multimedia learning (prinsip-prinsip dan aplikasi). Yogyakarta: Pustaka Pelajar.

Nurgiyantoro, Burhan. (2005). Sastra anak. Yogyakarta: Gadjah Mada University Press.

Nuryanti, Lusi. (2008). Psikologi anak. Jakarta: Indeks.

Rahim, Farida. (2009). Pengajaran membaca di sekolah dasar. Jakarta: Bumi Aksara.

Sugiyono. (2013). Metode penelitian pendidikan pendekatan kuantitatif, kualitatif, dan $r \& d$. Bandung: Alfabeta.

Susanto, Ahmad. (2013). Teori belajar dan pembelajaran di sekolah dasar. Jakarta: Prenadamedia.

Winaputra, (2008). Teori belajar dan pembelajaran. Jakarta: Universitas Terbuka.

Yulia, Anna. (2005). Menumbuhkan minat baca anak. Jakarta: PT. Gramedia. 